\title{
Urban Ecosystem Services: Carbon Fixation in the Permanent Preservation Areas of Campinas - SP
}

\author{
Rodrigo Semeria Ruschel \\ Antônio Carlos Demanboro
}

${ }^{I}$ Environmental Studies and Research Nucleus (NEPAM), State University of Campinas (UNICAMP).

Campinas/SP. Brasil.

"I Pontifical Catholic University (PUC-CAMP)

Campinas/SP. Brasil.

\begin{abstract}
This paper presents the potential of carbon fxation and the provision of ecosystem services from the Permanent Preservation Areas of the watercourses of Campinas-SP, with the objective of calculating the carbon abatement cost and comparing it with the marketable value of carbon credits. Study methodology used allometric equations to calculate above ground dry biomass. It was found that credits sales would cover up to $46 \%$ of project implementation costs. In addition to carbon fixation, the recovery of watercourse PPAs provides additional ecosystem services, which in a cost-benefit analysis of projects represent most of the total benefits. It was concluded that the inclusion of additional benefits proved to be fundamental in making the recovery of PPAs economically viable, generating revenue of US $\$ 44$ million, which corresponds to $98 \%$ of project implementation cost.
\end{abstract}

Keywords: Ecosystem services; reforestation; Carbon credits; Valuation.

São Paulo. Vol. 23, 2020

Original Article

DOI: http://dx.doi.org/10.1590/1809-4422asoc20170002r2vu2020L4AO 


\section{Introduction}

The human species has always benefited from the environmental services provided by the natural ecosystems. Concern with this theme began to grow from the mid-20th century on in view of the patent losses of those services as a result of anthropogenic pressures on the ecosystems (RARES; BRANDIMARTE, 2014).

According to the United Nations Organization (UNO, 2014), the urban population in 1952 was around 746 million inhabitants, representing 30\% of the total world population. By 2014 that number had jumped up to 3.9 billion inhabitants, representing $54 \%$ of the global total. In Brazil 185.35 million people live in urban areas, accounting for $85 \%$ of the population (UNO, 2016).

Santos (2014) considers that one of the major challenges in urban planning is how to reconcile the urban development process with conservation of natural resources using strategies that offer conditions to control and reverse the effects of socioenvironmental degradation such as flooding and illegal settlement of protected areas.

The continuous urbanization process engenders landscapes that are increasingly homogeneous, leading to biodiversity loss and the loss of ecological processes, functions and dynamics and consequently a dwindling offer of ecosystem services (ALBERTI, 2010; MELLO, et al., 2014).

Even though the market does not recognize the price of ecosystem service use, their economic value does exist, insofar as that use alters society's levels of production and consumption (wellbeing) (MOTTA, 1997) and goes far beyond the value associated to the commodities that those systems supply (DAILY, 1997).

An ecosystem can be defined as a system that comprises each and every living organism (biota) in it, their respective non-living (abiotic) environment and all the interactions among those components of the system, producing an energy flow and the cycling of materials (COMMON; STAGL, 2005; DAILY, 1997; ODUM, 1988).

In the definition proposed by Daily (1997), ecosystem services are products of the relations between the conditions, the processes and the species that exist in the natural ecosystem, that meet the demands of man. In addition to the natural ecosystems, denominated by economics as 'natural capital', Constanza et al. (1997) consider the relation of the ecosystem services with the stock of human and manufactured capital that results in services that guarantee social wellbeing.

A clear distinction must be made between ecosystem services and environmental services. The former refers to the contributions that nature makes to societies, that is, the benefits the natural ecosystems offer that humans enjoy, whereas the latter refers to human actions that favor the conservation or improvement of the ecosystems and consequently contribute towards the maintenance of the services those ecosystems provide (MMA, 2018).

Even though they are relatively protected from environmental changes by culture and technology, human beings are fundamentally dependent on the flow of ecosystem services. In that regard, it is highly important to study the dynamics of ecosystem services 
generation and their interactions with society, in addition to the impacts stemming from anthropic activities and economic growth on their capacity to generate those vital services.

According to Rares and Brandimarte (2014), several of those services have even greater importance in urban areas, not only because of the human population's dependence on them but also because of the fact that the heightened proximity with the population represents a serious threat to their maintenance.

Permanent Preservation Areas (PPAs) instituted by Brazil's New Forest Law (Act no 12.651/12) are described as "legally protected territorial spaces, environmentally fragile and vulnerable, that may be public or private, urban or rural, covered with native vegetation or not" (MMA, 2016).

The undesirable effects of the unplanned urbanization process, with its irregular settlement and inappropriate use of such areas has tended to reduce them and degrade them more and more. That makes it necessary to improve urban environmental policies directed at recuperating, maintaining, monitoring and supervising the PPAs in the cities (MMA, 2016)

Sepe et al (2014) go a little farther suggesting the need to discuss specific legislation to protect the urban areas of permanent preservation, whether they have any vegetation or not. It should be an Act which, at the same time that it facilitates acknowledgement of the highly diverse urban realities that exist in Brazil, guarantees the environmental preservation and recuperation of PPAs based on an identification of the functionalities such areas provide.

Martins (2004) considers that the carbon fixation potential of an ecosystem depends on the species that compose it, its age distribution and its structures. Other factors like climate, soil type and rainfall levels also influence the carbon fixation process.

Biomass gives a good estimate of the carbon reserves in forests because approximately 50\% of it is carbon (MACKDICKEN, 1997; MARTINS, 2004; IPCC, 2006). Estimates of biomass and carbon fixation potential can be obtained by direct methods, involving the physical collection and subsequent weighing of the vegetable material and indirect methods using allometric equations and/or satellite images (MACKDICKEN, 1997; MARTINS, 2004; MELO; DURIGAN, 2006; SILVA et al., 2015).

Constanza et al. $(1997 ; 2014)$ identify other ecosystem services, in addition to carbon fixation, that gallery forests can provide and which can generate a benefit of US\$ 5,382.00/ha.year. They underscore the importance of ecosystem services and their interactions with society, and of the impacts stemming from anthropic activities and economic growth on the ecosystems' capacity to generate those vital services.

In both the formal and voluntary markets, carbon compensation is measured in tons of carbon dioxide equivalent (CO2-eq). There is a wide range of variation in the price of carbon, going from less than US $\$ 1 / \mathrm{tCO}$-eq to as much as US $\$ 131 / \mathrm{tCO}$-eq,; 75\%of pricified emissions go for less than de US\$10/tCO2-eq (IBRAHIM; KALAITZOGLOU, 2016; PEREZ-VERDIN, 2016; WBG, 2016; ZAKERI et al., 2015).

In the short term, low carbon credit prices have a negative effect on the market, 
as do uncertainties and economic crises; they lead to a negotiated volume less than it could potentially be. However, there are certain measures that could benefit those markets and contribute to their greater efficiency. Among them are: adoption of more ambitious reduction targets by a greater number of countries; improvements in market regulation; a drop in transaction costs; and expansion of existing knowledge (GODOY; SAES, 2015).

It has been estimated that for carbon pricification to become an effective tool in complying with the Paris Agreement, the price of carbon needs to get up to somewhere in the range of US $\$ 80 / \mathrm{tCO} 2$-eq to US $\$ 120 / \mathrm{tCO} 2$ by the year 2030 (IPCC, 2014).

In the light of that consideration, this study sets out to estimate the carbon fixation potential of Permanent Preservation Areas accompanying the watercourses that lie within the urban perimeter of the municipality of Campinas (State of São Paulo) by elaborating various reforestation scenarios. It also investigates the feasibility of implanting reforestation projects using financial resources stemming from the sale of carbon credits generated by the project itself and the benefits accruing from the additional ecosystem services provision

\section{Case study - urban PPAs of Campinas, SP}

\section{The municipality of Campinas and its Permanent Preservation Areas}

The municipality of Campinas is located in the state of São Paulo (geographic coordinates $22^{\circ} 53^{\prime} 20^{\prime \prime} \mathrm{S}$ and $47^{\circ} 04^{\prime} 40^{\prime \prime}$ ) at an altitude of $680 \mathrm{~m}$ with an average annual rainfall of $1,372 \mathrm{~mm}$ and an average air temperature of $21.4^{\circ} \mathrm{C}$. The climate is $\mathrm{Cwa}$, according to the Köppen classification, that is, hot wet summers and cold dry winters (CAMPINAS, 2006; CEPAGRI, 2016).

The study used ArcGIS 10.1 software and a set of shapefile files supplied by the Municipal Government of the Campinas Department of Greenery and Sustainable Development (Secretaria do Verde e Desenvolvimento Sustentável) to elaborate a map of the Permanent Preservation Areas along the municipality's watercourses. Based on the delimitation of the urban area of the municipality, those water courses were classified as urban or rural according to whether they lay within or outside of the urban limits. The map is displayed in Figure 1.

Campinas has 10,594 hectares of PPA along its watercourses of which 7,579 hectares, (around 69\%) are degraded to a greater or lesser extent and only 3,375 hectares can be considered preserved. Within the urban limits there are 3,733 hectares of PPA, of which 2,763 are in a degraded state.

Based on the criteria adopted by the Municipal Green Plan (Plano Municipal do Verde) (CAMPINAS, 2016) and its classification of PPAs as Preserved or Degraded, it is considered that the degraded PPAs are apt for reforestation. 
Figure 1 - Areas of Preservation in Campinas. Those PPAs that lie within the urban limits are classified as urban PPAs and those that lie outside it as rural PPAs.

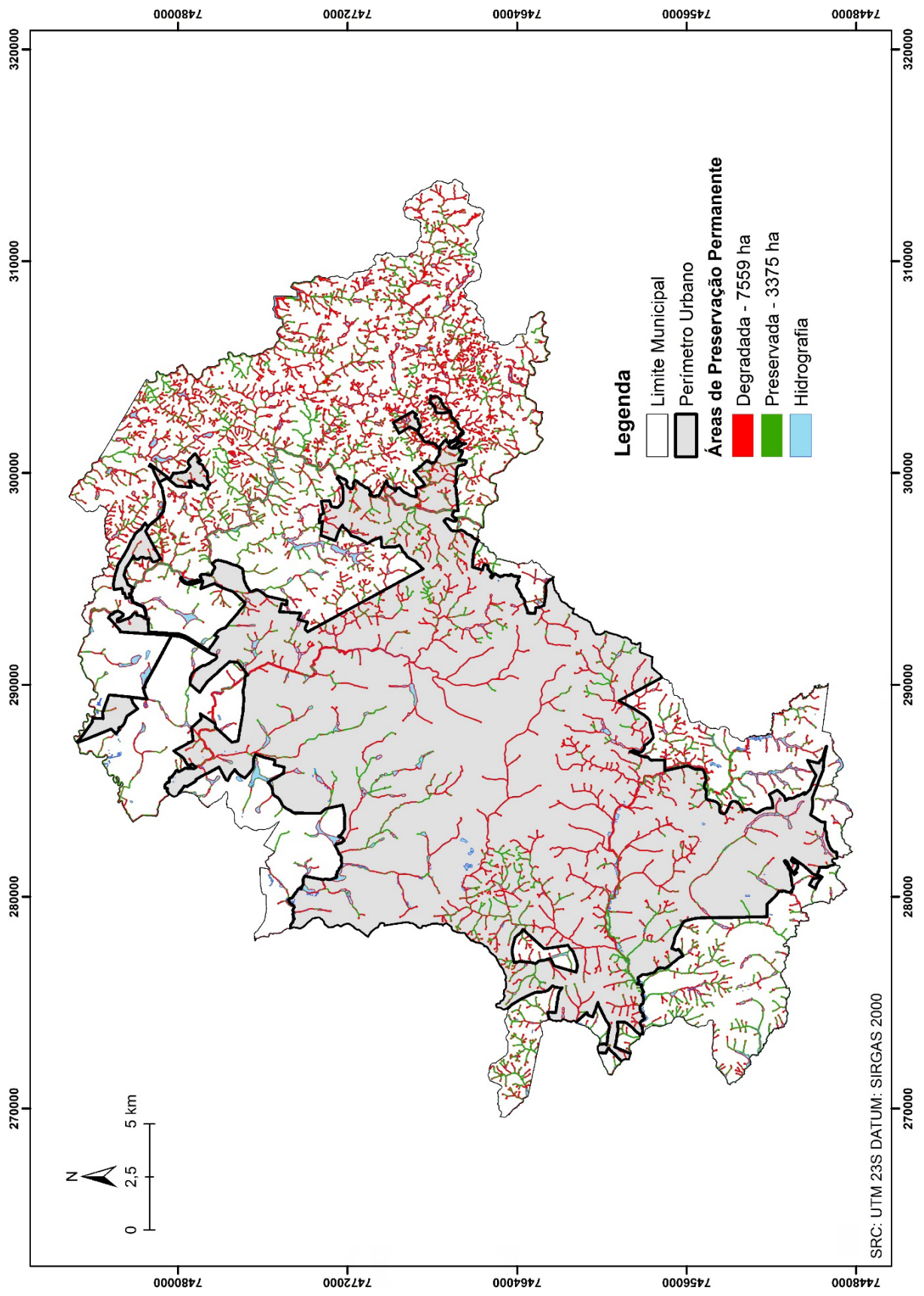

Source: the author, 2016. 


\section{Methodology}

\section{Calculation of carbon fixation potential}

The study adopted an indirect method using allometric equations to estimate the dry biomass above the soil. The respective formulae validated by the IPCC for reforestation projects are presented in Table 1 .

Table 1 - Equations used to calculate carbon fixation.

\begin{tabular}{c|c|c|c}
$\mathbf{N}$ & Equation & $\mathbf{R}^{2}$ & Author \\
\hline 1 & $\mathrm{Y}=\exp (-1,996+2,32 \times \ln (\mathrm{DAP}))$ & 0,89 & Brown (1997) \\
2 & $\mathrm{Y}=34,4703-8,0671 \times \mathrm{DAP}+0,6589 \times \mathrm{DAP} 2$ & 0,67 & Brown (1989); IPCC \\
3 & $\mathrm{Y}=\exp (-1,19829+1,98391 \times \ln (\mathrm{DAP}))$ & 0,86 & Lacerda et al. (2009) \\
\hline
\end{tabular}

Source: the author, 2016

Where: $\mathrm{Y}=$ Dry biomass above the soil per tree $(\mathrm{kg})$; DBHP $=$ diameter at breast height $(\mathrm{cm})$;

The value of the biomass obtained with the equations is divided by one thousand to express the result in tons. The value in tons is then multiplied by 0.50 to obtain the value in tons of organic carbon (IPCC, 2006).

To obtain an estimate of the carbon dioxide equivalent (CO2-eq), the value is multiplied by a factor of 3.67 (ratio of the molecular weight of $\mathrm{CO} 2$ to the atomic weight of Carbon) (IPCC, 2006; PEARSON, 2005).

To estimate the growth time of the seedlings and saplings for each diameter category this study adopted the average value of the Mean Annual DBH Increment, as obtained by Ferreira et al. (2007), of $1.10 \mathrm{~cm} /$ year.

\section{Proposed scenarios}

For the purpose of calculating the potential carbon fixation, the cost of implantation in one hectare, which corresponds to the planting of 1,667 seedlings with a spacing of $3 \mathrm{~m}$ X $2 \mathrm{~m}$ was calculated. Based on the values obtained for one hectare three different scenarios were elaborated according to the potential reforestation of the degraded urban PPAs, namely: scenario 1 with a potential of $30 \%$, scenario 2 , of $60 \%$ and scenario 3 , of $100 \%$.

For each scenario, diametric classes at DBH were established as $5 \mathrm{~cm}, 10 \mathrm{~cm}, 15$ $\mathrm{cm}$ and $20 \mathrm{~cm}$, simulating a seedling growth that was uniform and simultaneous in time and space.

In scenario one, the value of the carbon credits to be sold was taken to be US\$ $10 / \mathrm{tCO}$-eq. and that of the benefits generated by the ecosystem services would be US\$ 


\section{5,382/ha.year.}

Scenario 2 simulated an increase of $41.4 \%$ in the value of the carbon credit based on market studies so that the sale price for calculations was US $\$ 14.14 / \mathrm{tCO}$-eq. The additional benefits accompanied that valuation and were therefore quoted at US\$ 7,610.15/ha.year.

Scenario 3 simulates a valuation of $50 \%$ in comparison with the simulated value in scenario 2. Thus the credit is sold at US\$21.21/tCO2-eq and the additional benefit value becomes US\$11,415.23/ha.year.

The total cost of project implantation and the total amount of carbon fixation and $\mathrm{CO} 2$-eq, were estimated as well as the total value of the benefits generated by the additional ecosystem services for a period of 12 years after the plants were considered to have achieved the diametric class of 20 centimeters. The municipality of Campinas's capacity to address those different scenarios is analyzed based on the environmental indicators supplied by the municipal authority, namely: revenue related to environmental compensation commitments established with private agents and number of seedlings planted in a year

The values obtained using the three different equations were compared and the lowest value was adopted for each class. Table 2 displays the values obtained by the equations.

\section{Carbon pricification}

Based on market research and the author's personal experience with reforestation projects, the reference value established per seedling was US $\$ 9.73$. That value embraces reforestation project elaboration, submission to the respective body for approval, seedling procurement, and labor costs for planting and maintenance of the planted seedlings for two years. That minimum period is established in the municipal legislation of Campinas and is valid for all the environmental compensation projects in the municipality.

Table 2 - Comparison of carbon fixation and $\mathrm{CO} 2$-eq. of the results obtained by the three equations used to estimate associated value.

\begin{tabular}{|c|c|c|c|c|c|}
\hline \multicolumn{5}{|c|}{ Reforested area (ha) } & 1 \\
\hline \multicolumn{5}{|c|}{ Total number of seedlings } & 1,667 \\
\hline \multirow[t]{2}{*}{$\mathrm{DBH}(\mathrm{cm})$} & Equation & $\begin{array}{c}\text { Biomass } \\
\text { above ground } \\
(\mathrm{t} / \mathrm{ha})\end{array}$ & $\begin{array}{c}\text { Fixation of } \\
\text { carbon (t/ha) }\end{array}$ & $\begin{array}{c}\text { Fixation of } \\
\text { CO2-eq. (t/ha) }\end{array}$ & $\begin{array}{c}\text { Period of } \\
\text { growth (ano) }\end{array}$ \\
\hline & 1 & 9.478 & 4.739 & 17.391 & \\
\hline \multirow[t]{2}{*}{5} & 2 & 17.682 & 8.841 & 32.447 & 4.545 \\
\hline & 3 & 12.252 & 6.126 & 22.483 & \\
\hline
\end{tabular}




\begin{tabular}{llllll}
\hline \multirow{2}{*}{10} & 1 & 47.324 & 23.662 & 86.840 & \\
& 2 & 32.822 & 16.411 & 60.228 & 9.091 \\
& 3 & 48.466 & 24.233 & 88.935 & \\
\hline \multirow{2}{*}{15} & 1 & 121.232 & 60.616 & 222.460 & \\
& 2 & 102.881 & 51.441 & 188.787 & 13.636 \\
\hline \multirow{2}{*}{20} & 3 & 108.339 & 54.169 & 198.802 & \\
& 1 & 236.305 & 118.153 & 433.620 & \multirow{2}{*}{18.182} \\
& 2 & 227.859 & 113.930 & 418.122 & \\
\hline
\end{tabular}

Source: the author, 2016

Once the values for the carbon fixation and the cost of implanting one hectare had been defined, the cost associated to the ecosystem service of carbon fixation was calculated using the lowest values obtained by the three equations, as shown in Table 3 .

Table 3 - Costs associated to the ecosystem service of carbon fixation considering an exchange value for the American dollar against the real of 3.40

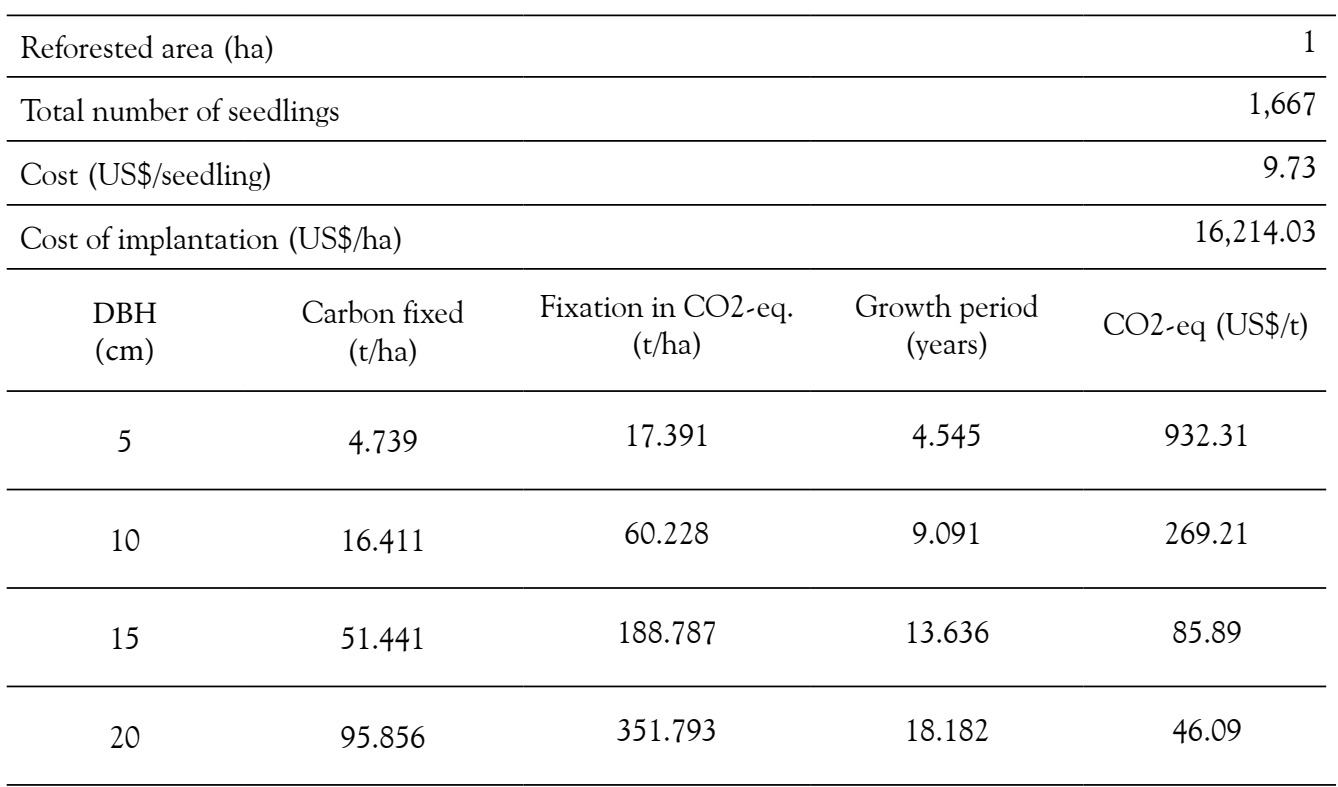

Source: the author, 2016

It must be stressed that this study restricted itself to considering the development of trees up to $\mathrm{DBH}$ of $20 \mathrm{~cm}$ in a period of 18 years. However, it is well known that trees continue growing and some species can easily go beyond a DBH of 30 centimeters (BROWN et al., 1989; MARTINS, 2004; MELO; DURIGAN, 2006; PREISKORN, 2011; TORRES 
et al., 2013). As mentioned earlier, the study made use of the lowest values obtained by the three equations so that the carbon fixation estimates are quite conservative.

Considering that $75 \%$ of the prices attributed to the carbon are below US $\$ 10$ / tCO2-eq (WBG, 2016), then clearly the cost of US $\$ 46,09 / \mathrm{tCO}$-eq in a time frame of approximately 18 years would be an obstacle to the viability of a reforestation project designed obtain the sale of carbon credits. The carbon pricification values adopted here are within the range foreseen by market studies and research (NORDHAUS, 2017; WBG, 2018).

However, Constanza et al. $(1997,2014)$ indicate that the practice of reforestation contributes other ecosystem services once the forest has been formed. It has been estimated that tropical forests generate benefits to the order of US $\$ 5,382.00 /$ ha.year (CONSTANZA et al., 2014). That being so, to analyze whether the total cost of a reforestation project would be compensated for by the value of the carbon credits plus the benefits of the other ecosystem services that the consolidated forest would provide and assuming that the total cost of implanting the reforestation would be paid in single payment, then it is possible to apply a cost-benefit analysis to the project.

To that end, the present day value must be calculated of the benefits stemming from the ecosystem services once the forest has achieved a satisfactory development and is capable of effectively providing those services. In the case of this study, it is considered that the forest would be capable of providing additional services as soon as the trees had attained a DBH of 20 centimeters. The values of the additional benefits were calculated as present day values for each year of the aforementioned period. An interest rate appropriate for a 10\% risk level was also taken into consideration as Valatin (2010) proposes.

An analysis period of 30 years was defined for the purpose of calculating the total value obtained from the additional ecosystem services in alignment with the IPCC (2006) guidelines for reforestation projects designed to obtain carbon credits. Accordingly, the period of analysis for this study was the 12 year period from year 18 to year 30 .

Once the calculations had been made for the reforestation of a single hectare then the same methodology was applied to estimate the carbon fixation values in $\mathrm{CO} 2$-eq and the cost associated to that ecosystem service for the three PPA recuperation scenarios for Campinas. It must be stressed that all the $\mathrm{CO} 2$-eq fixation estimates refer to trees with a DBH of 20 centimeters after a period of 18 years.

\section{Results and discussion}

\section{Scenario $1-30 \%$ of the potential PPA reforestation}

Given that the total area of urban PPAs with some degree of degradation is de 2,763 hectares, a potential reforestation of $30 \%$ refers 828.90 hectares, that would require 1,381,776 seedlings (1,667 seedlings/ha) to cover them. Considering the value of implantation as US\$9.73/seedling, the total cost to recuperate that area would be US\$ 


\section{$13,439,806.54$.}

It can be estimated that in this reforestation scenario, by the time the trees attained a DBH of $20 \mathrm{~cm}$ they would have fixed 291,601.324 tons of CO2-eq. From that diameter on, it is considered that the reforestation has attained its maximum in terms of carbon fixation because respiration and photosynthesis rates will be in equilibrium. From then on the forest will only contribute the additional ecosystem services with an estimated value of US $\$ 5,382.00 /$ ha.year. Putting them into present day values, the total benefits obtained in the period from year 18 to year 30 would generate US $\$ 6,255,714.24$ (vide Anexo III).

According to official data of the Campinas Department for Greenery and Sustainable Development (Secretaria do Verde e Desenvolvimento de Campinas - SVDS) (available at: http://ambientecampinas.wixsite.com/cidadaniaambiental/macorindicadores), in 2015 the municipality signed environmental commitment agreements to the tune of US\$ 8,037,352.94 (Terms of Conduct Adjustment and Terms of Environmental Commitment) and planted 67.471 seedlings.

Not all the money stemming from the environmental commitment agreements was invested in planting trees because such terms usually stipulate other compensatory measures that generate socioenvironmental benefits such as: constructing city squares, environmental education activities, handicraft workshops and others.

Therefore, to estimate the amount effectively allocated for planting seedlings, the study used the value of US\$28,27/seedling stipulated in Resolution no 04/2015 (CAMPINAS, 2015) issued by the municipal Department itself. It should be noted, however, that the value defined by the department does not correspond to the value being practiced in the market and is in fact three times greater than the latter.

On that basis it was estimated that of the total amount of environmental commitments that the municipality obtained in 2015 , only US $\$ 1,907,246.41$ were actually spent exclusively on reforestation; that is, $24 \%$ of the total commitment.

Even if the municipality were to dedicate the total amount of revenue from environmental commitments to the reforestation actions, it would not be enough to cover the cost of planting the 1,381,776 seedlings that would be needed to achieve the reforestation of $30 \%$ of the PPAs proposed in scenario 1.

Considering a market value of US\$9.73/seedling, the amount obtained in 2015 would only be sufficient for planting 826.338 seedlings; that is, only $60 \%$ of the total that should be planted in the proposed scenario.

If the municipality were to plant seedlings at the rate of 70 thousand a year, it would take 19.74 years for $30 \%$ of the urban PPAs in Campinas to be completely reforested, based on the premises assumed for this scenario.

One alternative that would increase municipal revenue and make it possible to recuperate the PPAs in less time would be to create a market for trading the carbon credits generated by the reforestation projects and that would be in alignment with the current proposals of the Green New Deal which includes significant innovations for solutions related to global climate change (USA, 2019) and the new tendencies identified by the 
World Bank (WBG, 2018).

In that case, the municipality could negotiate the credits, given that the reforestation projects are compulsory; the municipality signed terms of commitment to environmental compensation that do not permit the signatory to be directly benefitted by its own compensation. The municipality could benefit, however, from the sale of those credits in a regulated market.

That being so, if the municipality were to trade the credits at a price of US $\$ 10.00$ / tCO2-eq. it would generate a revenue of US $\$ 6,255,714.24$, that is to say, $21.70 \%$ of the implantation costs would be covered by the sale of the credits.

Adding on the amount obtained from the sale of carbon credits to the value of the benefits obtained from the additional ecosystem services, then an estimated US\$ $9,171,727.49$ would be obtained and the outstanding amount to be covered by other means would be just US $\$ 4,268,079.05$.

\section{Scenario $2-60 \%$ of the potential PPA reforestation}

Given that the total area of urban PPAs with some degree of degradation is 2,763 hectares, $60 \%$ of that figure is $1,657.80$ hectares which would require $2,763,553$ seedlings (1,667 seedlings/ha) to cover them. Considering an implantation cost of US $\$ 9.73 /$ seedling, the total cost of recuperating the area would be US $\$ 26,879,613.08$. In that $60 \%$ scenario, it is estimated that by the time the trees attained a DBH of 20 centimeters, 583,202.649 tons of CO2-eq. would have been fixed.

A valorization of $41.40 \%$ has been attributed to the benefits generated by the additional ecosystem services in this scenario. That is based on the estimated price per ton of CO2-eq., after the year 2030, of US $\$ 80$, designed to make the carbon credits market more attractive and useful as a tool to reduce the effects of climate change (IPCC, 2014; WBG, 2018).

Given that that carbon credit value will only be that high in year 18 then the value must be calculated in present day terms. The price of CO2-eq would therefore be US\$ 14.14 per ton.

Considering that adjusted value the additional ecosystem services would contribute US $\$ 7, .610 .15 /$ ha.year. That means the estimated total value of the benefits generated by the additional ecosystem services would be US\$17,691,164.53.

Trading the carbon credits stemming from the reforestation would generate revenue to the amount of US\$ $\$ 8,246,485.45$ considering the present day value of US $\$ 14.14$ / tCO2-eq. That revenue would be enough to cover $31 \%$ of the cost of implanting a project to recuperate $60 \%$ of the degrade PPAs.

If the value obtained by the sale of credits is added to the value stemming from the benefits provided by the additional ecosystem services, the amount recovered would be US\$25,937,649.99 leaving mere US\$ 941,963.10 to complete the amount of the total cost of project implantation. 
It must be reiterated that once again, to analyze the capacity of the municipality to bear the costs of reforestation of $60 \%$ of the degraded urban PPAs, the value used was the one presented by the respective municipal government department, the SVDS, in 2015.

As mentioned in regard to scenario 1 , of the total amount stemming from environmental compensation commitments the municipality obtained in 2015 , it is estimated that only US\$1,907,246.41 (24\%) were allocated exclusively to reforestation actions.

Considering the total amount committed to in 2015 and a cost of per seedling of US\$ 9.73, it would only be possible to plant 826.338 seedlings which is just $30 \%$ of the number that should be planted in this scenario.

If the municipality were to maintain a rate of planting 70,000 seedlings a year it would take 39.48 years before $60 \%$ of the urban PPAs in Campinas were completely covered with seedlings

\section{Scenario $3-100 \%$ of potential PPA reforestation}

The total area of totally or partially degraded urban PPAs is 2,763 hectares and 4,605,921 seedlings would be needed to plant them all (with a density of 1,667 seedlings/ ha). Taking the cost of implantation as being US $\$ 9.73 /$ seedling, the total cost of recuperating $100 \%$ of the areas would be US $\$ 44,799,355.14$. It can be estimated that in this $100 \%$ scenario, by the time the trees had attained a DBH of $20 \mathrm{~cm}, 972,004.414$ tons of $\mathrm{CO} 2$-eq. would have been fixed.

For this scenario the study estimated a 50\% increase in the value of the benefits generated by the additional ecosystem services. That enhancement is based on a maximum price per ton of CO2-eq, of US $\$ 120$, designed to make the carbon credits market more attractive and useful as a tool to reduce the effects of climate change (IPCC, 2014).

Given that the said carbon credit value would only be paid in year 18 , it needs to be translated to present day values. Thus, for this scenario the value of a ton of $\mathrm{CO} 2$-eq would be US\$21.21.

With that adjustment, the additional ecosystem services would contribute US\$ 11,415.23/ha.year. Thus the total estimated value of the benefits would be US\$ 44,227,930.71.

Sale of the credits generated by the reforestation project would generate revenue of US $\$ 20,616,213.63$, considering a value, per ton of CO2-eq adjusted to present day value, of US\$21.21. That amount would cover $46 \%$ of the implantation costs involved in recuperating $100 \%$ of the degraded urban PPAs

Adding the amount obtained from the sale of carbon credits to the amount obtained from the benefits of the additional ecosystem services, the estimated total would be US\$ $64,844,144.34$. Thus in this third scenario the project would be not only be viable but profitable as well, insofar as the amount obtained is greater than the cost of implementation by US $\$ 20,044,789.20$.

Considering that the planting capacity of the municipality of Campinas is a mere 
826,338 seedlings a year, that represents just $17.94 \%$ of the $4,605,921$ seedlings that it would need to plant to cover $100 \%$ of the city's degraded urban PPAs.

If the municipality were to plant 70,000 seedlings a year it would take 65.80 years before all the urban PPAs in Campinas were completely replanted with seedlings.

\section{Comparison of the scenarios}

In scenario 1 , where only $30 \%$ of the degraded urban PPAS would be recuperated, the revenue from the sale of the carbon credits the project would generate only covers $21.70 \%$ of the cost of project implantation, leaving an outstanding deficit of US\$ 4,268,079.05.

In scenario 2 with a valuation of $41.4 \%$ in the value of a carbon credit, the revenue would only cover $30.68 \%$ of the implementation cost. However, with the increase in the area reforested in this scenario there is also a gain in the benefits obtained from the additional ecosystem services which, according to the methodology applied, accompanies the valuation of the carbon credits. That means that around 26 million dollars in additional benefits would be generated, and that, added to the revenue obtained from trading the carbon credits would reduce the deficit to just US\$941,963.10.

In scenario 3, however, the situation is overcome and the project becomes economically profitable. In that case the amount obtained from the sale of carbon credits would represent almost $50 \%$ of project implantation costs and the additional benefits would cover the rest of the costs and engender a surfeit of twenty million dollars. In scenario 3 even if the carbon credits were not negotiated, the additional benefits of the ecosystem services stemming from reforestation would generate revenue of US $\$ 44,227,930.71$, and that alone would correspond to $98.72 \%$ of the total cost of implantation. That clearly demonstrates the importance of taking the additional ecosystem services into account in this kind of project. A summary of the values obtained for each scenario is set out in Table 4.

\begin{tabular}{|c|c|c|c|c|c|c|c|c|c|c|c|}
\hline 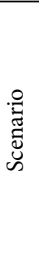 & 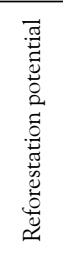 & 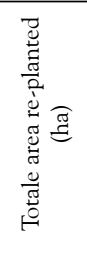 & 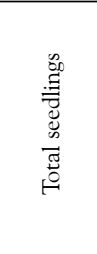 & 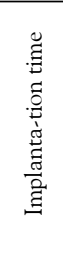 & 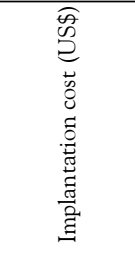 & 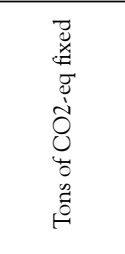 & 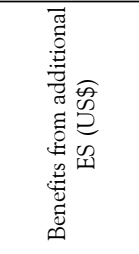 & 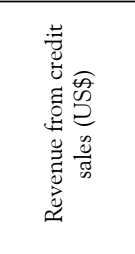 & 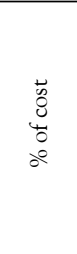 & 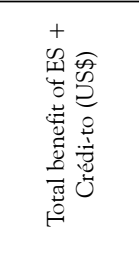 & 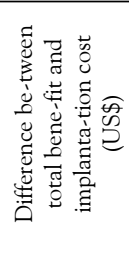 \\
\hline 1 & $30 \%$ & 828.90 & $1,381,776$ & 19.74 & $13,439,806.54$ & $291,601.324$ & $6,255,714.24$ & $2,916,013.24$ & $21.70 \%$ & $9,171,727.49$ & $-4,268,079.05$ \\
\hline 2 & $60 \%$ & $1,657.80$ & $2,763,553$ & 39.48 & $26,879,613.08$ & $583,202.649$ & $17,691,164.53$ & $8,246,485.45$ & $30.68 \%$ & $25,937,649.99$ & $-941,963.10$ \\
\hline 3 & $100 \%$ & $2,763.00$ & $4,605,921$ & 65.80 & $44,799,355.14$ & $972,004.414$ & $44,227,930.71$ & $20,616,213.63$ & $46.02 \%$ & $64,844,144.34$ & $20,044,789.20$ \\
\hline
\end{tabular}

Source: the author, 2016

Table 4 - Values obtained for each of the urban PPA scenarios.

As has been shown, even with an increase in the area to be reforested and a rise in 
implantation costs, the additional benefits were responsible for making the project viable. It is understood that carbon fixation occurs in a determined period of time as has been explained above. The additional ecosystem services, however, go on indefinitely provided the forests remain standing.

To calculate the total cost of the reforestation project implantation, the same value per seedling was used for all the scenarios. However, there is actually a variation in the price per seeding in the market according the greater or lesser number of seedlings to be planted. Accordingly, the total cost associated to project implantation could be less if one were to consider a progressive discount for greater numbers.

If the municipality of Campinas were to direct the total amount of the revenue from environmental compensation commitments, then, based on the values for 2015, it would have financial capacity to bear the cost of just 826,388 seedlings, which corresponds a mere $18 \%$ of the number needed to recuperate all of its degraded PPAs.

The difficulty the municipality faces in implanting reforestation projects could be attributed to the reference value established as US $\$ 28.27$. As shown earlier, that value is almost three times what is actually practiced in the market, according to the author's experience. It is therefore understood that the value established is designed to capture resources for other kinds of projects and not reforestation projects.

\section{Conclusions}

In regard to the viability of restoring PPAs along the banks of watercourses it was found that the municipality could benefit from the creation of a carbon credits market in which it could trade the credits generated by the reforestation. It showed that sale of such credits would cover as much as $46 \%$ of the costs of implementing the project. Possible purchasers for the credits would be companies that are engaged in environmental certification processes and seeking to compensate their emissions.

Using the funds accruing from the trading of carbon credits the municipality could stimulate voluntary sapling planting projects in condominiums and on the part of neighborhood associations, encouraged by publicity campaigns, thematic workshops and the distribution of educational material. Furthermore, more professional staff could be hired to enhance the municipality's power of surveillance which is one of the main obstacles in environmental affairs.

However, before a carbon market can be created, it is necessary not only to develop the plantations and their surveillance mechanisms but also to implant instruments that can guarantee the veracity of the respective data. To avoid frauds and effectively identify the responsibility of each agent in the process, it is essential that all the information should be trackable. Such measures, however, would probably mean that the project would incur additional costs. Once again, what we have here, is the suggestion of new solution for the present day market based on the innovative approach proposed by the Green New Deal. The creation of a carbon market for municipalities, enabling them to commercialize the credits generated by projects implanted in their territories is entirely aligned with those 
innovative approaches.

In addition to carbon fixation, the recuperation of the PPAs along the banks of the watercourses provides additional ecosystem services for the municipality. If those are taken into account in the cost-benefit analyses of the reforestation projects, then they represent the greater part of the total benefits. As explained above, the benefits generated by the additional ecosystem services make scenario 3 profitable. It can be understood, therefore, that the inclusion of the benefits generated by the additional ecosystem services is of fundamental importance insofar as it makes the recuperation of PPAs economically viable. Considering a discount rate of $5 \%$, as is the practice around the world, the difference would be 105 million dollars. That is a clear demonstration of how strongly the discount rate influences the profitability of a project.

It must be underscored that all the reforestation projects referred to in this study would be executed by means of environmental commitments made by private agents. The suggested trading in the credits those projects would generate would be an instrument for revenue collection for the municipality should it propose to use that revenue to complement the restoration of PPAs. However, as is known, it is not the municipality's intention to bear the expense of maintaining such projects, especially in private areas.

It must be underscored that all the reforestation projects analyzed in this paper would be executed by means of environmental commitments signed by private agents. The suggestion to trade carbon credits is made because it would be a means of obtaining revenue for the municipality should it be interested in complementing the efforts to restore the PPAs. However, it is common knowledge that the municipality is not interested in bearing the expenses of such projects, especially those in private areas.

Another important point is that this study only considered PPAs along watercourses within the urban limits of the municipality. However, PPAs in its rural areas also contribute by providing ecosystem services especially in the maintenance of the quality and quantity of water available in the sources of the watercourses. It is therefore suggested that further studies should investigate the question of ecological recuperation of those rural PPAs and their influence on the population's wellbeing.

It must not be forgotten how important Governmental and non-governmental programs that finance projects for the recuperation of PPAs are. However, the contributions of such projects have not been considered in this study as the investigation sought to assess the feasibility of the municipality of Campinas addressing the need to restore its PPAs independently.

\section{References}

ALBERTI, M. Maintaining ecological integrity and sustaining ecosystem function in urban areas. Current Opinion in Environmental Sustainability, v.2, n.3, p.178-184, 2010.

BRASIL. Lei nº 12.651 de 25 de maio de 2012. Dispõe sobre o novo Código Florestal Brasileiro. 
Diário Oficial da República Federativa do Brasil, Poder Legislativo, Brasília, DF, Seção 1, p. 1-8, 28 mai 2012.

BROWN, S.; GILLESPIE, A.J.R.; LUGO, A. Biomass estimation methods for tropical forests with applications to forest inventory data. Forest Science, Maryland, v.35, p.881-902. 1989.

BROWN, S. Estimating biomass and biomass changing of tropical forests: a primer. FAO FOrestry Paper, Rome, n.134, p.1-55, 1997. Disponível em:< http://www.fao.org/docrep/w4095e/ w4095e00.HTM> Acesso em: 12 de set. 2016.

CAMPINAS. Plano Diretor do Município. 2006

. Resolução n⿳o 04 de 28 de abril de 2015. Dispõe sobre o valor da muda plantada. Diário Oficial do Município, Campinas, p. 26, 29 abr. 2015.

. Secretaria Municipal do Verde e Desenvolvimento Sustentável. Plano Municipal do Verde: diagnóstico. Campinas: SVDS, 2016.

CEPAGRI. Centro de Pesquisas Meteorológicas e Climáticas aplicadas à Agricultura. Campinas, SP. Available at <http://www.cpa.unicamp.br/outras-informacoes/clima_muni_109.html> . Retrieved on: December 28, 2016.

COMMON, M.; STAGL, S. Ecological Economics: An Introduction. Cambridge: Cambridge University Press, 2005.

COSTANZA, R.; D’ARGE, R.; DE GROOT, R.; FARBER, S.; GRASSO, M.; HANNON, B; LIMBURG, K.; NAEEM, S; O’NEILL, R. V.; PARUELO, J.; RASKIN, R. G.; SUTTON, P.; VAN DEN BELT, M. The value of the world's ecosystem services and natural capital. Nature, Londres, v. 387, n. 6630, p. 253-260, mai. 1997.

CONSTANZA, R.; DE GROOT, R.; SUTTON, P.; VAN DER PLOEG, S.; ANDERSON, S. J.; KUBISZEWSKI, I.; FARBER, S.; TURNER, R. K. Changes in the global value of ecosystem services. Global Environmental Change, Amsterdam, v. 26, p. 152-158, 2014.

CONSTANZA, R.; CUMBERLAND, J. H.; DALY, H.; GOODLAND, R.; NORGAARD, R. B.; KUBISZEWSKI, I.; FRANCO, C.; An introduction to Ecological Economics. Estados Unidos, Florida: CRC Press, 2015.

DAILY, G. C. (Ed.) Nature's Services: Societal Dependence on natural ecosystems. Washington, DC: Island Press, 1997.

FERREIRA, W. C.; BOTELHO, S. A.; DAVIDE, A. C.; FARIA, J. M. R. Avaliação do crescimento de estrato arbóreo de área degradada revegetada à margem do Rio Grande, na usina hidrelétrica de Camargos, MG. Revista Árvore, Viçosa-MG, v. 31, n. 1, p. 177-185, 2007.

GODOY, S. G. M.; SAES, M. S. M. Cap-and-trade e projeções de redução de emissões: Comparativo entre mercados de carbono, evolução e desenvolvimento. Ambiente e Sociedade, São Paulo, v. 18, n. 1, p. 141-160, 2015.

IBRAHIM, B. M.; KALAITZOGLOU, I. A. Why do carbon prices and price volatility change. Journal of Banking and Finance, Amsterdam, v. 63, p. 76-94, 2016.

INTERGOVERNMENTAL PANEL ON CLIMATE CHANGE - IPCC. Good practice guidance for land use, land-use change and forestry. Japão: Institute for Global Environmental Strategies (IGES), 2003. 
TREJO-HERNANDEZ, V.; LINARES-MARQUEZ, M. A. Economic valuation of ecosystem services in Mexico: Current status and trends. Ecosystem Services, Amsterdam, v. 21, p. 6-19, 2016.

PREISKORN, G. M. Composição florística, estrutura e quantificação do estoque de carbono em florestas restauradas com idades diferentes. 2011. 130 f. Dissertação (Mestrado em Recursos Florestais), Universidade de São Paulo, 2011.

RARES, C. S.; BRANDIMARTE, A. L. O desafio da conservação de ambientes aquáticos e manutenção de serviços ambientais em áreas verdes urbanas: o caso do Parque Estadual do Cantareira. Ambiente e Sociedade, São Paulo, v. 17, n. 2, p. 111-128, 2014.

SANTOS, A. S. S. Diretrizes para implantação de sistemas de infraestrutura verde em meio urbano: Estudo de caso da cidade de Ribeirão Preto-SP. 2014. 192 f. Dissertação (Mestrado em Engenharia Urbana), Universidade Federal de São Carlos, 2014.

SILVA, H. F.; RIBEIRO, S. C.; BOTLEHO, S. A.; FARIA, R. A. V. B.; TEIXEIRA, M. B. R.; MELLO, J. M. Estimativa do estoque de carbono por métodos indiretos em área de restauração florestal em Minas Gerais. Scientia Forestalis, Piracicaba, v. 43, n. 108, p. 943-953, dez. 2015.

TORRES, C. M. M. E.; JACOVINE, L. A. G.; SOARES, C. P. B.; NETO, S. N. O.; SANTOS, R. D.; NETO, F. C. Quantificação de biomassa e estocagem de carbono em uma Floresta Estacional Semidecidual, no Parque Tecnológico de Viçosa-MG. Revista Árvore, Viçosa, MG, v. 37, n. 4, p. 647-655, 2013.

THE WORLD BANK: CLIMATE CHANGE - WBG. State and trends of carbon pricing. Washington, 2016.

. State and trends of carbon pricing. Washington, 2018.

USA. 116th Congress. H. Resolution 109: Recognizing the duty of the Federal Government to create a Green New Deal. 2019. Available at: https://www.congress.gov/116/bills/hres109/ BILLS-116hres109ih.pdf. Retrieved on: May 29, 2019.

VALATIN, G. Forests and carbon: valuation, discounting and risk management. Forestry Commission Research Report. Forestry Commission, Edinburgh, 2010.

ZAKERI, A.; DEHGANIAN, F.; BEHNAM, F; SARKIS, J. Carbon pricing versus emissions trading: A supply chain planning perspective. International Journal of Production Economics, Amsterdam, v. 164, p. 197-205, 2015.

TELLES, D.D. ; COSTA, R.H.P.G. Reúso da água: Conceitos, teorias e práticas. São Paulo: Blucher, 2. ed., 2010.

TOEBE, C. S. et al. Consciência ambiental: o olhar dos filhos de produtores rurais e dos discentes de cursos vinculados às atividades rurais. XX Jornada de Pesquisa - UNIJUI, Porto Alegre, 2015.

TOMAZ, P. Água: pague menos (livro eletrônico). 1a ed. O autor. 2010, 137p. Disponível em: $<$ http://www.pliniotomaz.com.br/downloads/livros/livro_pague_menos/livro_pague_menos. pdf>. Acesso em 24 abr. 2017.

TUAN, Yi-Fu. Topofilia - Um Estudo da Percepção, Atitudes e valores do Meio Ambiente. São Paulo: Difel, 1980. 288p. 
UCKER, F. E.; et al. Elementos interferentes na qualidade da água para irrigação. Revista Eletrônica em Gestão, Educação e Tecnologia Ambiental. v. 10, n. 10, p. 2102-2111, jan/abr. 2013. URBANO, V.R. Aplicação de água de reúso tratada no cultivo de alface (Lactuca Sativa L.). Dissertação (Mestrado). Universidade Federal de São Carlos - São Carlos, 2013, 87p.

VON SPERLING, M. V.; CHERNICHARO, C. A. L. Biological Wastewater Treatment in Warm Climate Regions, (Vol. 1). IWA Publishing, London, UK, 2005, 1496p.

WHYTE, A. 1978. La perception de Lenvironnement: lignes directrices méthodologiques pour les études sur le terrain. Notes techniques du MAB 5. Paris: UNESCO, 134 p. 


\section{Rodrigo Semeria Ruschel}

๑r211675@dac.unicamp.br

ORCiD: https://orcid.org/0000-0001-8502-165X

\section{Antônio Carlos Demanboro}

$\square$ ademanboro@gmail.com

ORCiD: https://orcid.org/0000-0002-4708-9714
Submitted on: 17/05/2017

Accepted on: 20/01/2020

2020;23:e00022

How to cite: RUSCHEL, R. M.; DEMANBORO, A. C.. Urban Ecosystem Services: Carbon Fixation in the Permanent Preservation Areas of Campinas - SP. Ambiente $\mathbb{E}$ Sociedade. São Paulo, v. 23, p. 1-19, 2020. 


\title{
Serviços Ecossistêmicos Urbanos: Fixação de Carbono nas Áreas de Preservação Permanente de Campinas-SP
}

\author{
Rodrigo Semeria Ruschel \\ Antônio Carlos Demanboro
}

São Paulo. Vol. 23, 2020

Artigo Original
Resumo: Este trabalho apresenta o potencial de fixação de carbono e provisão de serviços ecossistêmicos das Áreas de Preservação Permanente dos cursos d'água do município de Campinas-SP, com o objetivo de calcular o custo de abatimento de carbono e compará-lo com o valor comercializável de créditos de carbono na Bolsa de Valores. A metodologia baseou-se no uso de equações alométricas, visando calcular a biomassa seca acima do solo. Como resultado obteve-se que a comercialização dos créditos cobriria até $46 \%$ dos custos de implantação dos projetos. Além da fixação de carbono, a recuperação das PPAs dos cursos d'água proporciona serviços ecossistêmicos adicionais, que ao serem contemplados na análise custo-benefício dos projetos representam a maioria dos benefícios totais. Conclui-se que a inclusão dos benefícios adicionais mostrou-se fundamental para tornar a recuperação das PPAs economicamente viável, gerando uma receita de US\$ 44 milhões, que corresponde a $98 \%$ do custo de implantação do projeto.

Palavras-Chave: Serviços ecossistêmicos; reflorestamento; crédito de carbono; Valoração.

Como citar: RUSCHEL, R. M.; DEMANBORO, A. C.. Serviços Ecossistêmicos Urbanos: Fixação de Carbono nas Áreas de Preservação Permanente de Campinas-SP. Ambiente \& Sociedade. São Paulo, v. 23, p. $1-19,2020$. 


\title{
Servicios ecosistémicos urbanos: fijación de carbono en las áreas de preservación permanente de Campinas-SP
}

\author{
Rodrigo Semeria Ruschel \\ Antônio Carlos Demanboro
}

São Paulo. Vol. 23, 2020

Artículo original
Resumen: Este documento presenta el potencial del secuestro de carbono y la provisión de servicios ecosistémicos de las Áreas de Preservación Permanente de los cursos de agua de Campinas-SP, con el objetivo de calcular el costo de reducción de carbono y compararlo con el valor comercializable de créditos de carbono. La metodología se basó en el uso de ecuaciones alométricas para calcular la biomasa seca sobre el suelo. Se descubrió que la venta a crédito cubriría hasta $46 \%$ de los costos de implementación del proyecto. Además de la captura de carbono, la recuperación de los PPA proporciona servicios ecosistémicos adicionales, que representan la mayoría de los beneficios totales. Se concluyó que la inclusión de beneficios adicionales demostró ser fundamental para hacer que la recuperación de PPA sea económicamente viable, generando un ingreso de US \$ 44 millones, que corresponde al 98\% del costo de implementación del proyecto.

Palabras-Llave: Servicios de los ecosistemas; reforestación; créditos de carbono; valoración.

Como citar: RUSCHEL, R. M.; DEMANBORO, A. C.. Servicios ecosistémicos urbanos: fijación de carbono en las áreas de preservación permanente de Campinas-SP. Ambiente $\mathbb{\&}$ Sociedade. São Paulo, v. 23, p. 1-19, 2020. 